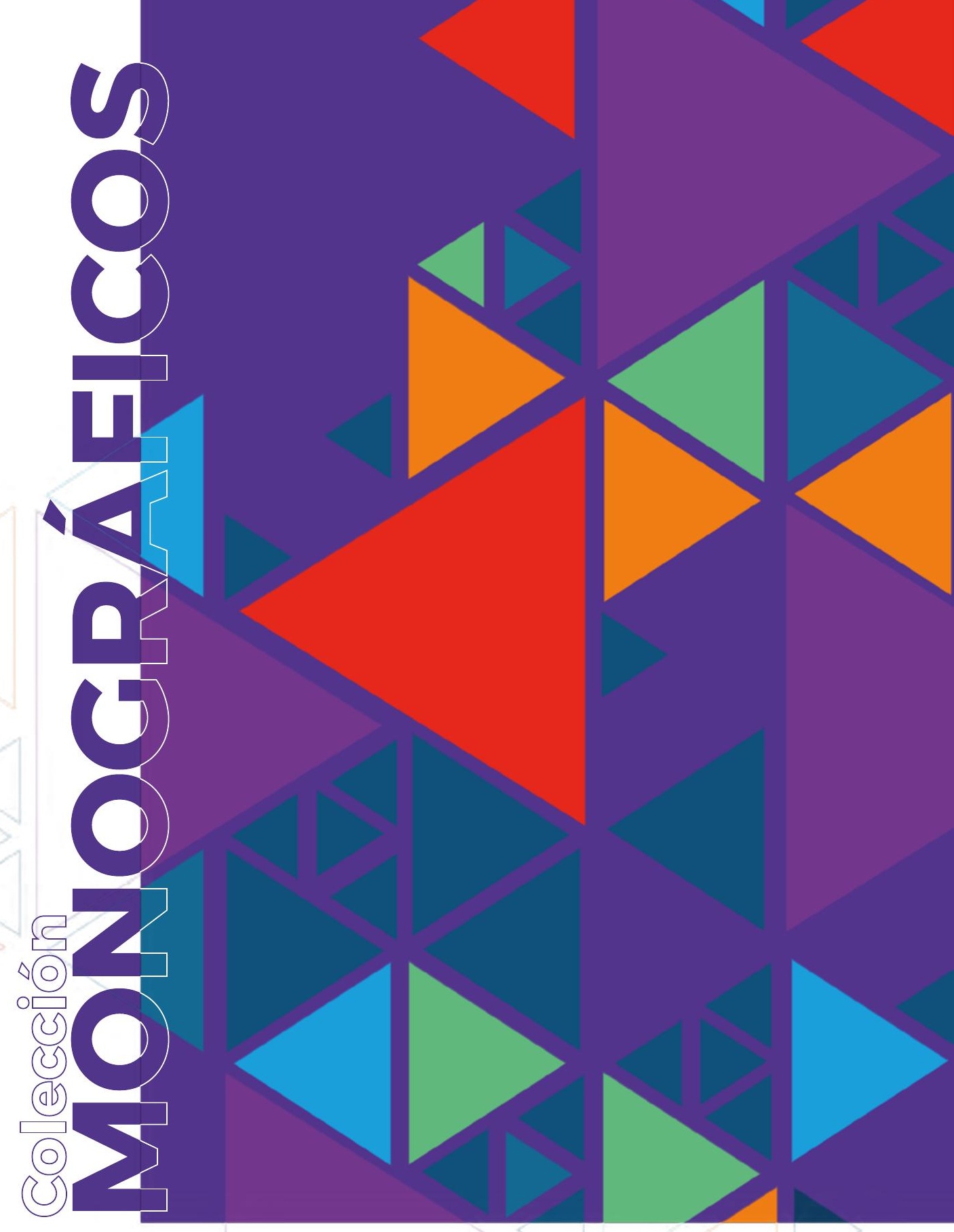

Understanding EFL students' learning through classroom research: Experiences of teacher-researchers

Sandy T. Soto Compiler 
Ediciones UTMACH

117 pág: $21 \times 29,7 \mathrm{~cm}$

Colección Monográficos

Title: Understanding EFL students' learning through classroom research: Experiences of teacher-researchers - Sandy T. Soto

(Compiler)

First edition 2020

ISBN: 978-9942-24-137-5

CDD 607

1. Education,

2. Research

3. EFL teaching

--Related topics

PDF publication 


\title{
Understanding EFL students' learning through classroom research: Experiences of teacher-researchers
}

\author{
Sandy T. Soto
}

COMPILER

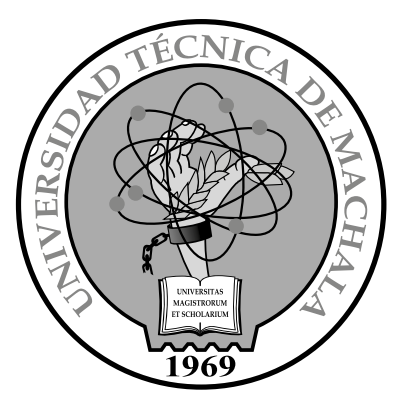




\section{Authorities}

César Quezada Abad - Rector Amarilis Borja Herrera - Academic Vice-rector Jhonny Pérez Rodríguez - Administrative Vice-rector

Luis Brito Gaona

Research Director

(c) Ediciones UTMACH Colección Monográficos

Original title:

Understanding EFL students' learning through classroom research: Experiences of teacher-researchers ISBN: 978-9942-24-137-5

(c) Sandy T. Soto

(Compiler)

(c) Chapter authors

DOI: http://doi.org/10.48190/9789942241375

First edition 2020

Karina Lozano Zambrano Editor in Chief / Editorial edition and design

Fernanda Tusa Jumbo - Proofreader Jorge Maza-Cordova - Associate editor Karla Ibañez y Cyndi Aguilar - Promotion team

This book is under a Creative Commons Attribution Non-Commercial License. This license allows others to intermix, adjust and build from your work for noncommercial purposes, as long as they recognize the authorship and their new creations are under a license with the same terms. 


\section{Dedication}

To those EFL teachers who, day by day, give the best of their own for helping their students construct their knowledge and learn

English in meaningful and effective ways.

Sandy T. Soto 

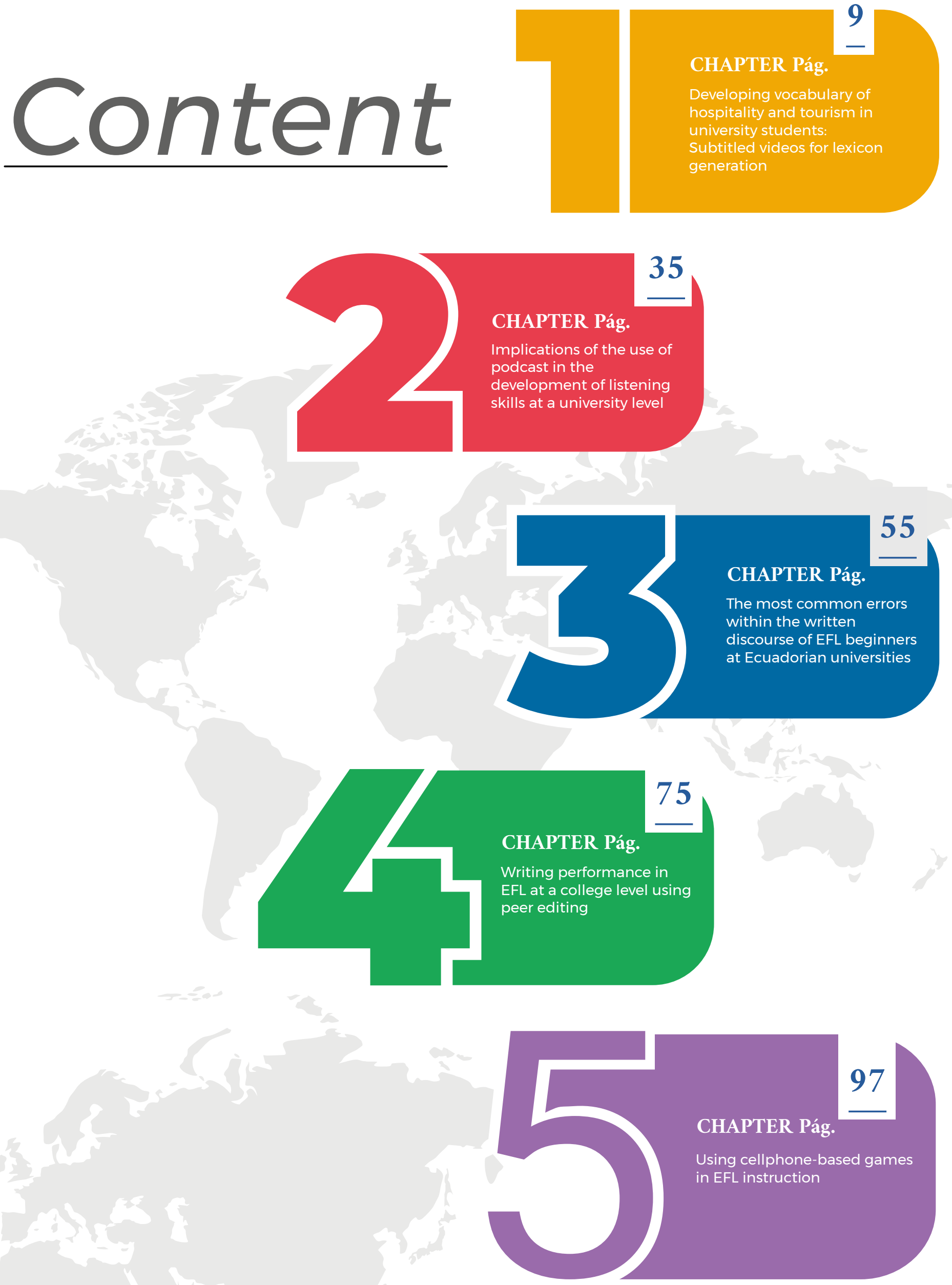


\section{Introduction}

What should foreign language teachers do to help their students improve their linguistic skills? Many are the ways how teachers can support their students' learning process. There are a variety of methods, strategies, techniques, as well as materials and resources we can rely on in order for our students to succeed in the development of their skills.

Teachers can get ideas on what to do from published research, presentations at academic events, informal conversations with colleagues, online resources, and their own language learning experience. It is just a matter trying these ideas out and evaluate the extent to which they favor the enhancement of students' linguistic competences in the target language.

In line with these ideas, this book is intended to inform pre-service and in-service EFL teachers about the result of investigations conducted by English as foreign language teachers. The book is composed of five chapters which demonstrate how these teachers have taken a step further by taking the role of teacher-researchers to understand and boost their students' performance.

The first chapter of this book reports on a study conducted at the university level where students majoring in Hospitality and Tourism participated as principal users of videos to develop vocabulary of their field. The study aimed to find out the opinions of students about the use of English subtitled videos or movies to develop tourism vocabulary and to explore the benefits of using English subtitled videos in a context where there is no practice of the target language outside the classroom.

The second chapter of this book focuses on the development of listening skills through the use of podcasts as a strategy and resource in EFL classes. The aim of the study was to discuss the importance of podcasts for teaching English as a foreign language and to analyze the results of using them to improve listening comprehension in university students.

The third chapter digs into the writing skill. It is based on an interuniversity investigation in which the authors identified the most common errors made by EFL beginning level college students in their written discourse. The identification of these errors can guide EFL teachers to make methodological decisions to improve their students' writing performance.

The fourth chapter also addresses writing. In this case, this chapter discusses how a group of college students developed their writing skills through the writing of paragraphs and peer correction. Students wrote e-mails, blogs, reviews and posts and used rubrics to evaluate their performance with the help of their peers. 
Finally, chapter seven examines the use of cell phone games within English classes. The chapter seeks introduce these games as a valuable resource to encourage the practice of English through mobile phones in and out of the classroom. Concepts of mobile games and the reason to use them in EFL classes are addressed. The chapter also provides some suggestions of game applications developed to support the learning of EFL. 


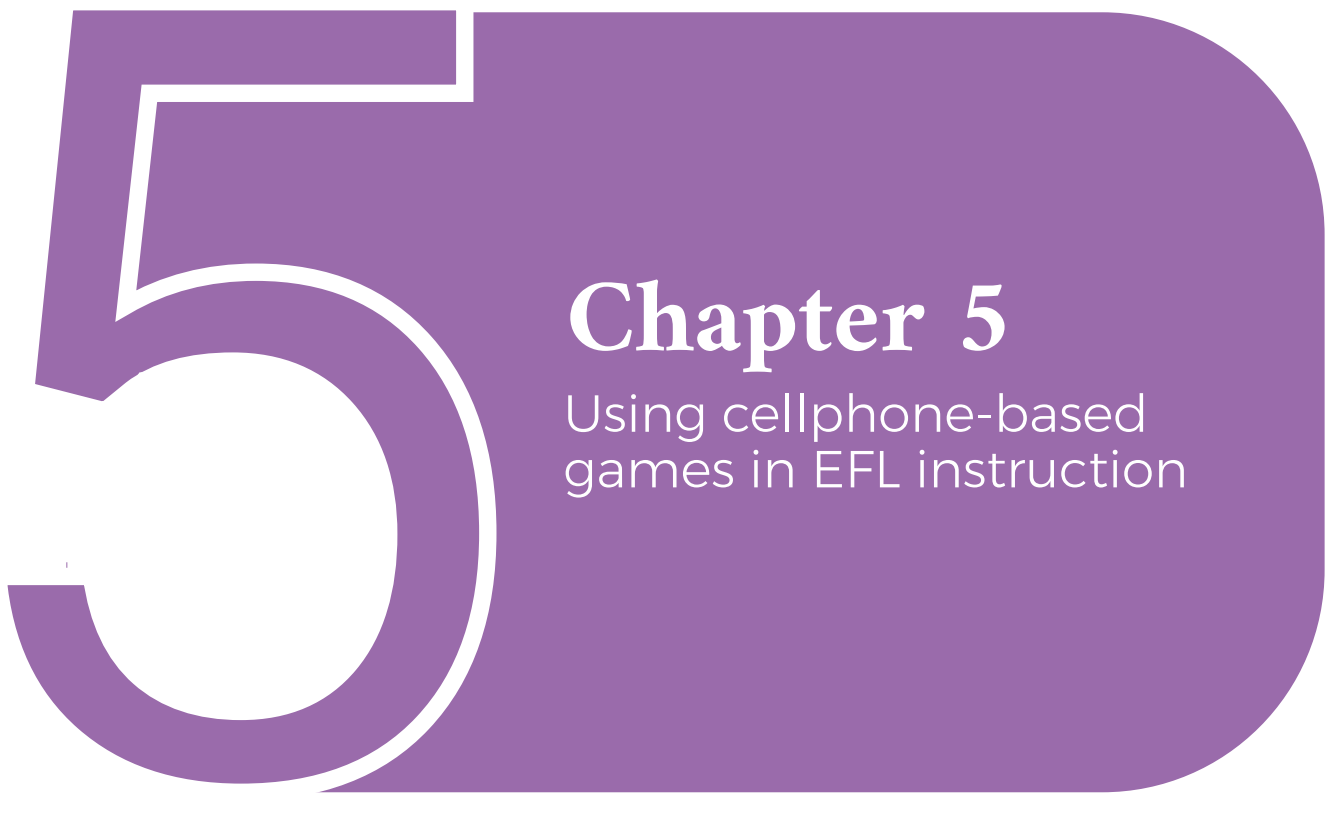




\title{
Using cellphone-based games in EFL instruction
}

\author{
Sandy T. Soto \\ Ligia Fernanda Espinosa Cevallos \\ José Pomavilla
}

Authors 


\section{Using cellphone-based games in EFL instruction}

\section{Sandy T. Soto}

Student of the doctoral program in Advanced English Studies: Linguistics, Literature, and Culture at Universidad de Vigo, Spain. She holds a Master's degree in Curriculum and Instruction ESL from Kansas State University and a Bachelor's degree in EFL Teaching from Universidad Técnica Particular de Loja. She teaches ESP at the Academic Unit of Business Sciences of Universidad Técnica de Machala, Ecuador. She coordinates the ELT Innovators research group adjunct to UTMACH. Her research interests include didactics for EFL teaching and learning, educational policies applied to TEFL, curriculum design and materials development, and professional development for EFL teachers.

\section{Ligia Fernanda Espinosa Cevallos}

Professor and researcher at Universidad Regional Amazónica IKIAM. She holds a Master's degree in Curriculum and Instruction with emphasis in ESL from Kansas State University. The author has published several articles and books related to English learning, and has presented in national and international conferences organized by TESOL organizations.

\section{José Pomavilla}

Holds a Master's degree in Curriculum and Instruction ESL from Kansas State University and a Bachelor's degree in English Language Teaching from Universidad Nacional de Chimborazo. Currently, he is an English teacher at Yachay Tech University. He coordinates the virtual English teaching program in the English department. José is interested on doing research about online languages teaching, ancestral languages, and curriculum design.

DOI: http://doi.org/10.48190/9789942241375.5 


\section{Abstract}

The advent of technology has influenced education, even in the most remote parts of the world. Nowadays, it is totally normal for a person to have some technological devices such as laptops, iPads, tablets, and especially cell phones. Ecuador is not far from this reality. Moreover, in the English Language Learning Standards, the Ministry of Education suggests using technological resources in teaching (eg internet, software, computers and related devices). Given this warm welcome to the use of technology in Ecuador's English classes, as well as the number of students using cell phones in Ecuador, this chapter is intended to provide basic information on the use of cell phone games within English class. It is intended that English teachers become aware of the powerful tool that cell phones represent for their classes and encourage the practice of English through mobile phones in and out of the classroom. Throughout the document, general information on mobile games and the reason for their use in EFL classes will be provided. This information will be accompanied by the description of several game applications that have been developed for using in the EFL teaching-learning process.

Keywords: Games, cellphone-based games in EFL, technology in education, cellphone apps, mobile-based games in Ecuador, mobile-assisted language learning, cooperative learning.

\section{Introduction}

The technological advances the world has gone through since some decades ago have not only impacted the business, communication, and science fields. The advent of technology has also influenced the education field. Consequently, it is not hard to find any sort of technological tools within the educational settings, even in the most remote parts of the globe.

As a matter of fact, technology has become an important part of the life of nearly every individual in the planet. Today, technology is accessible for everyone and has become a significant tool for daily interaction and as Googin (2006) noted, it has become an international phenomenon. Hence, it is totally normal that a person owns technological devices such as laptops, iPads, tablets, and especially cellphones; more than one device in some cases. The results of the survey administered by Fundación Telefónica, in 2011, support this fact. This institution conducted a survey for the Ecuadorian Ministry of Telecommunications with the purpose of finding out about the utilization of the TV, computers, videogames, and cellphones by children and adolescents of different urban and rural schools in Ecuador. Regarding the use of cellphones, the data gathered from this survey showed that preceded by the $87 \%$ of the utilization of this technological gadget for communication purposes, 
the $55 \%$ of the survey respondents stated that they used their cellphones for playing games (Bringue \& Sabada, 2011).

Governments around the world are promoting the use of technology inside the classrooms by introducing technology components in their curriculum (Bidin \& Ziden, 2013). Ecuador is not far from this reality. For instance, in the English Language Learning Standards established for the EFL curriculum, the Ecuadorian Ministry of Education (ME) noted that English teachers should "use technological resources (e.g., internet, software, computers, and related devices) to enhance language and content-area instruction for students" (Ministerio de Educación, 2012, p. 5). Furthermore, through the official agreement 70-14 issued on April 17th, 2014, the ME introduced some regulations that allow the use of cellphones in the class as long as it is for educational purposes (Miniterio de Educación, 2014).

Considering this warm welcome to the use of technology in Ecuadorian classrooms as well as the increasing number of students who own cellphones, this paper has the purpose of providing some grounding information for English language teachers about the utilization of cellphones-based games within their instruction. The authors of this work intend to make English teachers aware of the powerful tool cellphones represent for their teaching. English teachers can take advantage of the utilities these devices provide and promote the utilization of game applications to foster their students' language practice and development by playing games on their cellphones, both inside and outside the classroom setting or as Bidin \& Ziden (2013) mentioned "anytime and anyplace" (p. 721).

Throughout the paper, the authors provide general information about games and a rationale about why EFL instructors should use them. Relevant information about the utilization of cellphones as a technological tool inside the classroom as well as a teaching approach regarding the application of mobile technology is also detailed. The authors also include background information about the utility of apps in EFL instruction as well as the description of several cellphone game applications which have been meticulously selected for EFL instruction. A summary of strategies recommended for effective employment of cellphone-based games is also offered. Finally, the authors close this chapter with the specification of an overview about the limitations and applications of cellphone-based games in Ecuador.

\section{What are games?}

There are many definitions about games. For instance, among some of its dictionary meanings, the online dictionary WordReference.com defines a game as "an amusement or pastime" or "an activity in which players compete against others, involving skill, chance, or endurance and played according to a set of rules for the amusement of the players or of spectators". Similarly, the Merriam-Webster.com defines game as "a physical or mental activity or contest that has rules and that people do for pleasure". 
In addition, Deesri (2002) stated that in educational langauge learning settings, games are strategies or activities used to foster the acquisition of a second langauge as as claimed by Byrne (1995) in Deesri (2002) they are a mean to have the second language learners practice the language while playing. Moreover, by practicing their language skills through well-selected games, students are also given a chance to relax from the usual pattern of their classes (Ersoz, 2000).

\section{Why should EFL teachers use games in their classrooms?}

English teachers should consider using games in their classrooms for a varitety of reasons. Games provided teachers useful tool to grab the learners' attention, reduce the level of anxiety in the students, and provide students opportunities for practicing the langauge in authentic situations as their main purpose is to promote students' learning and amusement at the same time (Deesri, 2002).

Moreover, Ersoz (2000) stated that games can reduce the frustation behind the difficultness of learning a new language. Games help to achieve this as they serve as a vehicle to motivate and challenge students while they are having fun using the langauge in real contexts and cooperating with other students. Also, Korbey (2014) revealed that games are a useful tool to benefit students with low achievement performance or those who struggle with the subject content. And more importantly, as noted by Shapiro (2014), the use of games develop the students' social and meta-cognitive skills as well as their motivation and emotions.

\section{Cellphones in the Classroom}

Just as we previously stated, having access to technology in the classroom is not far from our hands anymore. Furthermore, when talking about technology, computers are not the only devices teachers can take advantage of in their instruction as there are other types of electronic devices such as cellphones, tablets, iPads, etc., which are accessible through the students themselves (Bidin \& Ziden 2013). Even though some schools have policies against the use of cellphones in the class, in most educational institutions, students keep bringing their cellphones to the school as a personal technology tool (Ormiston, 2014). In this regard, Edward (2014) mentioned that every day there are more people who own a cellphone and counting with smartphones in the class can improve the pedagogical practice.

Bidin \& Ziden (2013) highlighted several positive points for cellphones. Cellphones are functional and portable. They promote privacy for learning as well as self-regulated, flexible, interactive, collaborative, fun, and life-long learning. Due to their irrefutable positive features, "the use of mobile phones and other portable devices is beginning to have an impact on how learning takes place in many disciplines and contexts, including language learning” (Kukulska-Hulme, 2009, p. 158).

In their part, Todd \& Tepsuriwong (2008) stated that regardless of the impor- 
tance of cellphone use in educational environments, these technological devices have not been well exploited for language learning in the classroom. In addition, as a concern to the under-use of this technological device, Ormiston (2014) proposed to deliberate about the use of cellphones for learning as the advantages these tools offer are not only for in class opportunities but also for extending the learning over the borders of the classroom or the school itself. Regarding this point, Kukulska-Hulme (2009) stated that mobile devices are a significant asset for teaching and learning as "learners who are not dependent on access to fixed computers can engage in activities that relate more closely to their current surroundings, sometimes crossing the border between formal and informal learning” (158).

Authors such as Kukulska-Hulme (2002), Waycott, Scanlon and Jones (2002), and Keegan (2003) cited in (Bidin \& Ziden, 2013), on the other hand, are skeptical about the durability of the usage of mobile devices in the classrooms. These authors argue that the utilization of mobile gadgets can decrease due to the drop-in students' excitement towards working with such tools as well as the suitability of activities performed in these devices within the content under study.

\section{Mobile-Assisted Language Learning}

Mobile-Assisted Language Learning or commonly referred as MALL, is a teaching/ learning approach that deals with the use of mobile devices such as cellphones for language learning (Rodríguez-Arancón, Arús, and Calle, 2013; Miangah \& Nezarat, 2012; Chinnery, 2006). This mobile-based teaching approach facilitates language learning in terms of freedom as learners are not bound to the class periods or the classroom walls to practice the language (Bidin \& Ziden, 2013). For instance, learners can make use of the time to learn through their mobiles when they are doing travelling, outdoors, or any free time they have at work. Furthermore, Kukulska-Hulme et al (2011) in Rodríguez-Arancón, Arus, \& Calle (2013) stated that mobile "devices can offer learning opportunities that are: spontaneous, informal, contextual, portable, ubiquitous, pervasive, and personal” (p. 1189).

Moreover, Miangah \& Nezarat (2012) stated that "mobile learning can take place either within the classroom or outside it. In the former case, mobile phones possessing appropriate software are very effective in collaborative learning among small groups. Although this type of learning has nothing to do with the mobility property of such devices, it provides the learners with the opportunity of close interaction, conversation, and decision-making among the members of their group due to the specific design of the learning activity on mobile phones" (p. 311).

Miangah \& Nezarat (2012) also indicated that among the novelties of Mobile-Assisted Language Learning is game-based learning which deals with the linking of "the real world of knowledge and the visual world of the game" (p. 311). Regarding second language learning, mobile learning can serve a useful tool to 
teach second language and help the learners to develop their skills in areas such as "vocabulary, pronunciation, grammar, listening and reading comprehension and spelling” (Miangah \& Nezarat, 2012, p. 311-312).

\section{Cellphone Apps}

Apps are software that mobile devices users can install on their cellphones or any other mobile tool. These programs allow cellphone owners to perform activities in their phones such as sending emails, surfing on the web, playing, etc. Basic apps such as the contact list app and the camera normally come included in your cellphones and tablets. Otherwise, other apps such as books, games, movies, etc., can be downloaded to the devices so that the users can do the activities they enjoy doing (Verizon, 2014).

\section{Cellphone Apps in EFL/ESL Instruction: Views and Studies}

Applications produced by operating systems such as Google's Android, Apple's iOS, and Microsoft's Windows 7 have become a potential technological tool for EFL instruction as they can enhance learning either in a collaborative or individual way. People learning English as a Second Language can learn anytime and anywhere by using a wide variety of applications they can download in their cellphones, tablets, etc., (Rodríguez-Arancón, Arus, \& Calle, 2013).

Targeting English language learning, as stated by Cui \& Wang (2008), considering that game apps are found in every cellphone, it is in the hands of programmers and game designers to elaborate meaningful game apps for educational purposes so that cellphone users can utilize them for learning. These authors also considered that the creation of educational game apps can be a great advantage as people can develop their critical thinking and problem-solving skills by playing this type of games, plus, playing games is an engaging practice. Consequently, students who are learning English would feel more attracted towards the acquisition of this language by playing games. Moreover, today, there are memorization games that can be used for instructional purposes; also, "games, such as word shooting, would be especially helpful and meaningful to English learners because they can learn words while playing games." (p.78).

While having a conversation with a student who was willing to improve his English language skills, P’Rayan (2011) recommended him to use his smartphone to improve his abilities within this langauge. He claimed that people who own an Android mobile have the possibility to download thousands of applications to learn and practice English. For instance, English langauge learners can download "apps such as dictionaries, thesauri, crossword puzzles, interactive error correction quizzes, reading comprehension exercises, pronunciation practice and news stories (texts and audio)” (Learning ESL / EFL Using Smartphones, 2011). Regarding 
games, Crosswords is one of the applications he recommended as this app allows the learner to practice their language by solving crossword puzzles. In addition, in other article wrriten by the same author, P'Ryan (2012) stated that "[Students] don't depend on teachers or classroom teaching. They depend on technology and various English learning apps for smart phones to develop their English language skills. They are familiar with English learning apps that include grammar, pronunciation and vocabulary improvement" (English Learning Apps for Smart Phones, 2012).

Upadhyay \& Upadhyay (2007) conducted mobile-based games for second langauge learning pilot project study in India. In their study, Indian students were provided with a match game and a word game for second langauge learning. The word game consisted on answering some questions about synonyms and antonyms at different complexity levels that increases as the students answer each question. By playing this mobile-based word game, students were fostered to build their vocabulary.

The match game, on the other hand, consited on arranging sentences for proper grammar construction and on choosing the grammaticaly incorrect word or phrase within the sentence. This game fostered the students grammar knowledge. As a result of this study, Upadhyay \& Upadhyay concluded that the use of cellphones for learning a second language was effective and easy for students. In addition, by using mobile-based games, students' increased their level of interest towards learning a second language as well as the learning process was easy as the students could learn wherever and whenever they wanted.

Moreover, Hockly (2013) described the results of a survey aplied to two groups of "international EFL learners studying at a private language school in the UK". This survey was conducted by The International Research Foundation in English Language Education about the use of mobile devices regarding "communicative language learning tasks" during a project where the students were enhanced to use any mobile device during class to conduct the tasks aforementioned. The results of the survey applied to the students showed that "the majority of the class enjoyed using mobile devices $[\ldots]$, and would like to continue to do so in the future $[\ldots]$. The majority also felt that using their mobile devices had improved their English $[\ldots]$, and their mobile literacy $[. .$.$] by familiarizing them with new apps such as$ Chirp, Audiobook, Woices, and new mobile-related concepts such as QR codes $[\ldots]$.

\section{Game-Apps: Examples and Description}

There are many applications that can be downloaded to mobile devices and used for English teaching/learning purposes. Below are some examples of free apps for Android mobile devices. 


\section{WordSearch Unlimited}

Figure 1: Sample of Images of Word Search Unlimited
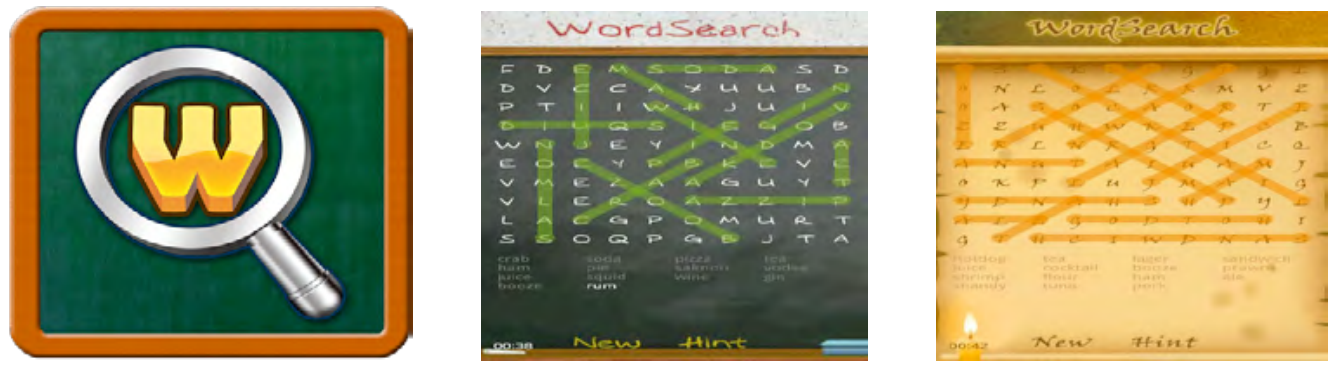

Retrieved from: https://play.google.com/store/apps/details?id=com.virtuesoft.wordsearch

WordSearch Unlimited is a word puzzle game. The online mode of WordSearch Unlimited allows players "to play with other players in the real time." Users can also "play unlimited high-quality puzzles, with themes [they] like." Game features: "Play with other players in the online mode. Unlimited puzzles: each puzzle is unique. Three game levels. Word lists from popular categories. Word lists with foreign words. Local scoreboard. [...]. Word lists: Basic, standard English words, SAT vocabulary, GRE vocabulary, Animals, Food \& Drink, Fruit \& Vegetable, Family, Boy names, Girl names, Body parts, Colors, Sports, Football Players, Music \& Instruments, Flowers, Famous Brands, Transport, Weapons, Weather, World countries, German words, French words, Spanish words, Italian words (Google, 2014).

\section{Word Shaker}

Figure 2: Sample of Images of Word Shaker
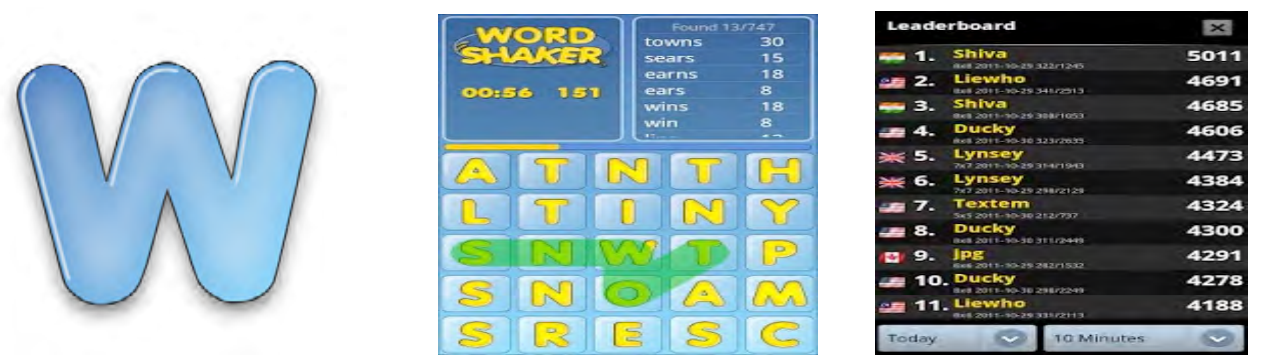

Retrieved from: https://play.google.com/store/apps/details?id=com.afksoft.WordShakerAndroidFree

Word Shaker is a "word searching game with a twist". In this game, "words don't have to be in a straight line" The players" "goal is to earn the most points by finding words in a grid. Each letter has a particular point value, and [the players] earn bonuses by forming longer words". This game is connected with online leaderboards where the players can "compete with friends and people around the world" (Google, 2014). 


\section{Hangman}

Figure 3: Sample of Images of Hangman
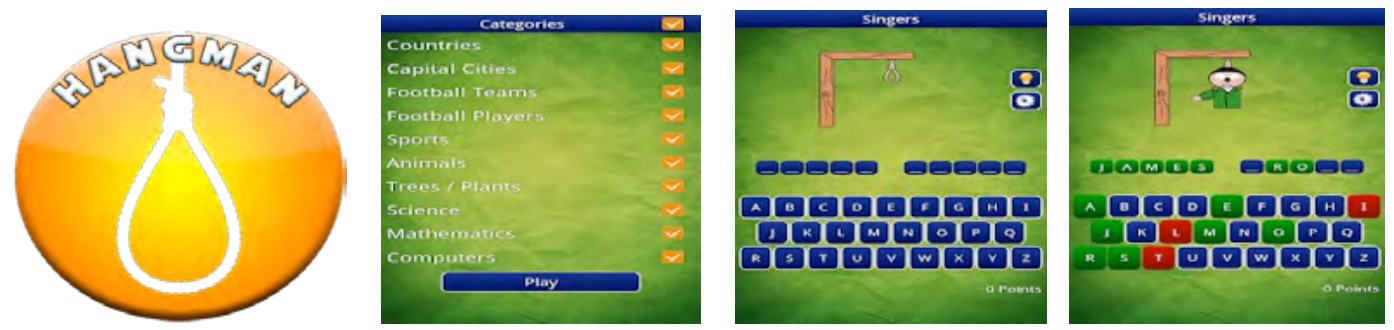

Retrieved from: https://play.google.com/store/apps/details?id=com.ricardoalves.hangman.pt

Hangman is a guessing game by which players can have fun by themselves or with friends. "The game consists of 1700 words divided into 20 categories" [...] the game offers [players] three different modes of play": Normal game, against time, and 1vs 1game. In the normal game, the players guess the word and increase their score. In the against time game, the players are given time to guess the words. And, in the 1vs 1 game, the players can play against a friend (Google, 2014).

\section{Guess the Emoji}

Figure 4: Sample of Images of Guess the Emoji
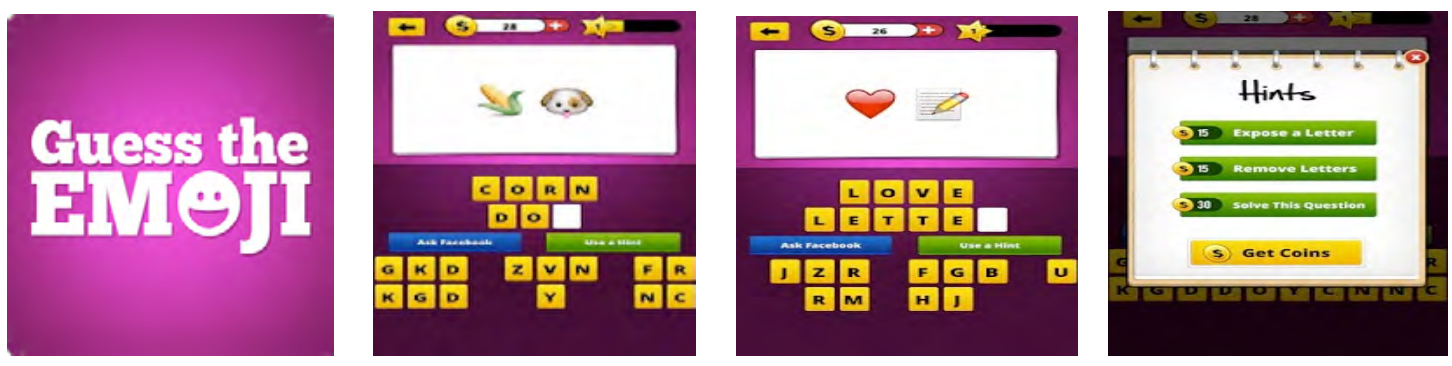

Retrieved from: https://play.google.com/store/apps/details?id=com.randomlogicgames.guesstheemoji

Guess The Emoji is a friendly guessing game that tests the users' "logic and reasoning skills to solve simple (and sometimes hard!) Emoji Puzzles!” Users are "presented with a screen displaying some emojis" and they have to guess what the emoticons are describing. Users are provided hints if they are stuck on a hard emoji question (Google, 2014). 


\section{English Vocabulary Test}

Figure 5: Sample of Images of English Vocabulary Test
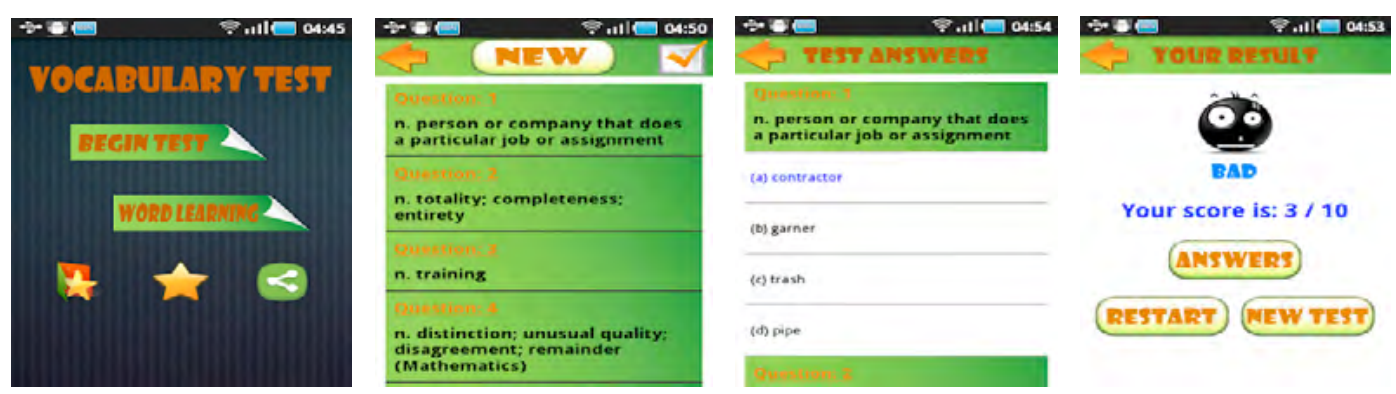

Retrieved from: https://play.google.com/store/apps/details?id=vocabulary.test

English Vocabulary Test is a useful tool to test and learn English Vocabulary. This application is designed for any person. It contains "thousands of words, from basic to advanced which are divided into more than 650 tests" for players to learn English words easily. The players or users will receive a score and the correct answers of each tests after users finish it (Google, 2014).

\section{Category Quiz}

Figure 6: Sample of Images of Category Quiz
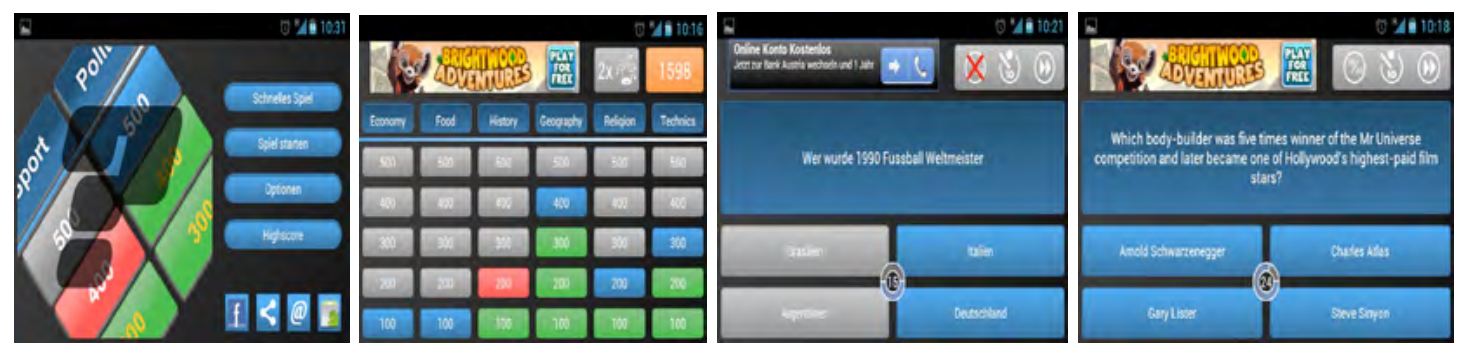

Retrieved from: https://play.google.com/store/apps/details?id=hmas.category.quiz

Category Quiz is a trivia game. In this game, questions are to be answered by category. The questions are divided into the following categories: sports, entertainment, food and drinks, geography, science, history, arts and literature, people, music, plants, politics, religion, technology, animals, and economy. While playing, players can change the categories freely. Within this game, if the player answers all the questions of one category are answered correctly, the player receives 100 extra points. If a second category is answered correctly, 200 extra points are given to the player, and so on (Google, 2014). 


\section{Practice English Grammar-Sam}

Figure 7: Sample of Images of Practice English Grammar-Sam
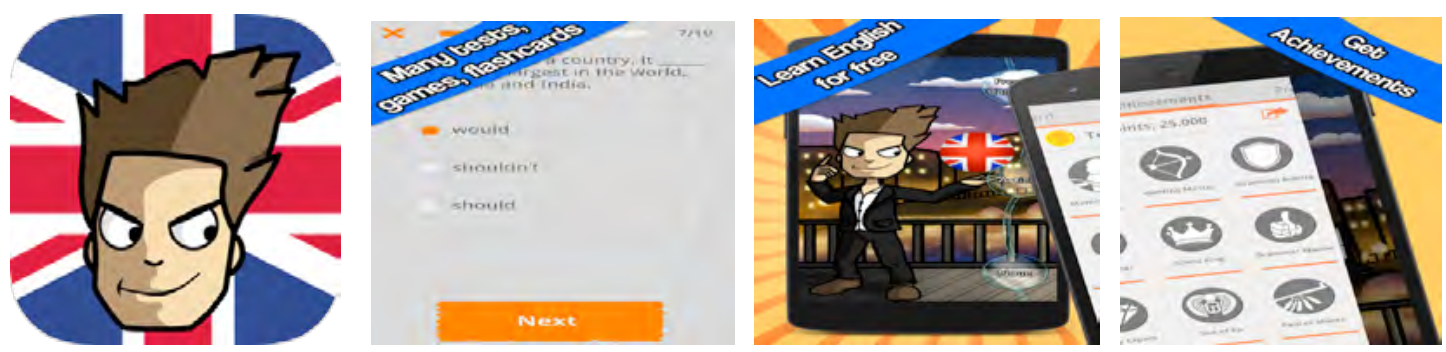

Retrieved from: https://play.google.com/store/apps/details?id=com.testsstore.app

Practice English Grammar-Sam is a grammar application where the users can improve their English grammar by solving interesting grammar exercises. Users can unblock the levels and compare the results with their friends. Within the program, users accompany Sam in exciting adventures as he crosses different eras. In those adventures, users help Sam to solve English grammar challenges. In addition, users can compete with their friends or with players from other parts of the world as they learn English grammar in an entertaining way (Google, 2014).

\section{Johnny Grammar's Word Challenge}

Figure 8: Sample of Images of Johnny Grammar's Word Challenge
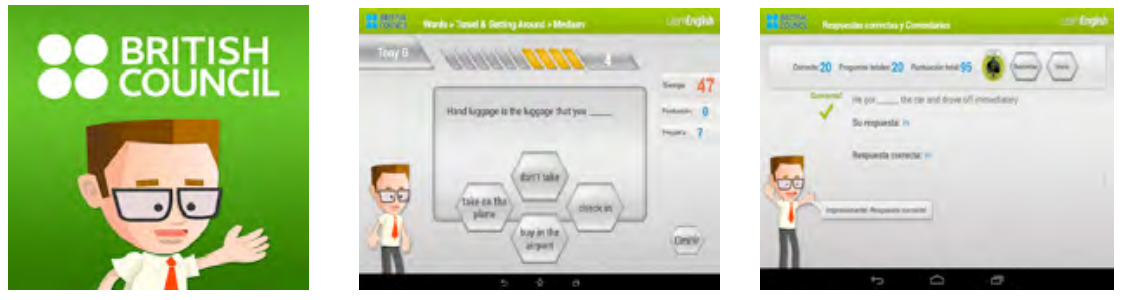

Retrieved from: https://play.google.com/store/apps/details?id=com.ubl.spellmaster

Johnny Grammar's Word Challenge is as one-minute quiz where the players have to "answer as many spelling, vocabulary and grammar questions as" they can. "Johnny Grammar's Word Challenge is a quiz for English learners to test common vocabulary, spelling and grammar that appears in everyday English". This game is composed by "3 quiz categories - Words, Grammar, Spelling. 3 levels - Easy, Medium, and Hard. 10 common topics - Food \& Restaurants, Travel, Small Talk, Hobbies etc." Players can: "earn badges as [they] play and share with others. Compete with others on a global leaderboard. Share [their] badges with others on a leaderboard". This application also provides feedback on wrong answers to enhance the learning (Google, 2014). 
Applications like these can be used as a mean for English learning in EFL instruction. EFL teachers can take advantage of those mobile-based games for in class activities and have the students practice vocabulary and grammar in English. For instance, students may practice and increase their vocabulary by playing WordSearch Unlimited, Word Shaker, Hangman, Guess the Emoji, English Vocabulary Test, and Category Quiz. In addition, they may practice their grammar knowledge by playing Practice English Grammar-Sam and Johnny Grammar's Word Challenge.

\section{Cooperative Learning as a Teaching Strategy for Mobile-Based Games EFL Instruction}

Cooperative learning, as suggested by Arnold (1999) and Ellen (2002), is a group activity which requires the participation and contribution of all the individuals that belong to that group. Students become responsible for their own learning and to learn from each other. Furthermore, cooperative tasks enhance learner's higher attainment since they have the opportunity of talking with peers and clarify any doubts which will help them to participate more actively in their tasks (Ellen, 2002). Consequently, since individuals receive support from their partners, they will achieve more when working in groups than making efforts individually.

As students are fostered to learn and practice English by playing games on their mobile devices such as cellphones, teachers can have the students compete with other peers in pairs or they could also compete in groups. By working on competitions, students are motivated to work cooperatively. Students can collaborate and support each other while playing the game and at the same time increase their knowledge about grammar and vocabulary in English. Consequently, having the students work in pairs or groups when playing games on their cellphones, teachers can promote cooperative learning as a learning strategy in their EFL classroom.

\section{Discussion}

\section{Practical Applications of Mobile-Based Games in Ecuador}

Mobile-based games can represent a great asset for EFL instruction in Ecuador. English language teachers can promote their students' English language learning by practicing grammar and vocabulary through cellphone game applications. Consequently, utilizing the appropriate cellphone game app could be an excellent reinforcing activity for the content being taught. Furthermore, as games represent fun, mobile-based games can be such an excellent mean to make English classes more active and engaging for EFL students.

Students who are not English fans or those who struggle with the language can find playing mobile-based games useful and attractive to improve their skills 
regarding grammar and vocabulary as well as in other language skill areas. Besides, applying game apps effectively can promote students' interaction as they work in cooperative learning tasks during their instruction. Finally, EFL teachers can take advantage of this practical device and the opportunities mobile-based games offer to them through game apps to assess their students formatively.

\section{Problems and Limitations for the Utilization of Cellphone-Based Games in} Ecuador

Some of the problems or limitations that English language teachers may face regarding the use of cellphone-based games in Ecuadorian classrooms have to deal with the management and access to adequate cellphones for this purpose inside the classrooms. For instance, considering that the utilization of cellphones for educational purposes has just started to be promoted by the Ecuadorian government, teachers may not have the necessary knowledge or training about how to apply these devices in their instruction adequately.

Also, even though statistics report that Ecuadorian students have access to cellphones more and more every day, not all parents may allow their children to bring a cellphone to school. Regarding this point, it is also important to contemplate the possibility that if students are able to do so, not all their cellphones may be appropriate for downloading applications. Some students own cellphones that only have basic utilities. Although the game applications proposed here are free, another point to mention is accessibility to certain apps that may not be free. Furthermore, as most of these apps only work with Internet access, this may be a big limitation. Neither the students may have Internet access in their cellphones nor may the school be able to supply wireless internet connection for the students work in their mobile devices.

\section{Conclusions}

Today, teachers are surrounded by a variety of innovative ideas about how to give technology practical uses to improve their instruction for the benefit of their students. Moreover, the application of informational technologies has become part of today's curricula around the globe. Therefore, it is important that teachers make a wise and practical use of the technological devices they have to their disposition; either provided by the schools or from the students themselves.

Regarding technology, one of the technological gadgets EFL teachers can take advantage of in Ecuadorian school settings are cellphones. Cellphones are the most frequent technological devices students have access to in Ecuador. Bearing this in mind, plus the support that the Ecuadorian government is providing to the 
use of cellphones for educational purposes in Ecuador, the application of cellphones-based games can offer a variety of opportunities for EFL instruction in Ecuadorian schools.

For instance, EFL teachers can use their creativity and imagination to make of the utilization of cellphone games apps a powerful and rich activity to support EFL students' language learning. Besides, by cooperating and collaborating among one another, students can demonstrate and scaffold their knowledge as they receive support from their peers. Finally, besides utilizing cellphone-based games for promoting an enriching, interactive, and engaging environment in EFL classes, the utilization of cellphone game apps can provide a canvas of opportunities for teachers to find out how much their students have progressed and what gaps still need to be fulfilled. In conclusion, technology is a powerful tool for education and cellphone-based games provide a practical utility for EFL teachers to help students scaffold their learning. Teachers can achieve this as by working on cellphone-based games, students have the chance to practice and to demonstrate what they have already grasped. Also, students can also demonstrate what still needs to be internalized so that teachers can take actions about it and accommodate their instruction to foster their students' English language learning success. 


\section{References}

Agnes Kukulska-Hulme (2009). Will mobile learning change language learning?. ReCALL, 21, pp 157-165. Doi:10.1017/S0958344009000202.

Arnold, J. (1999). Affect in Langauge Learning. Cambridge: Cambridge University Press.

Bidin, S., Ziden, A.A. (2013). Adoption and application of mobile learning in the education industry. Procedia-Soc. Behav. Sci., 90, 720-729. Doi: https://doi.org/10.1016/j.sbspro.2013.07.145

Bringue, X., \& Sabada, C. (2011). La generacion interactive en Ecuador - Ninos y adolescentes ante las pantallas. Quito: Telefonica Ecuador. Retrieved from http:// www.scribd.com/doc/61621486/La-Generacion-Interactiva-en-Ecuador

Chinnery, G. (2006). Emerging teachnologies going to the MALL: Mobile assisted language learning. Language Learning \& Technology, 10, 9-16. Retrieved from http://www.llt.msu.edu/vol10num 1/pdf/emerging.pdf

Cui, G., \& Wang, S. (2008). Adopting cell phones in EFL teaching and learning. Journal of Educational Technology Development and Exchange, 1, 69-80.

Deesri, A. (2002, September). Games in the ESL and EFL class. The Internet TESL Journal, 8. Retrieved from http://iteslj.org/Techniques/Deesri-Games.html

Edward, G. (2014, July 15). NEA National Education Association. Retrieved from Using Smartphones in the Classroom: http://www.nea.org/tools/56274.htm

Ellen, L. (2002). Creative Planning Resource for Interconnected Teaching and Learning. New York: Peter Lang Publishing, Inc.

Ersoz, A. (2000). Six games for the EFL/ESL classroom. The Internet TESL Journal, 6. Retrieved from http://iteslj.org/Lessons/Ersoz-Games.html

game. 2014. In Merriam-Webster.com. Retrieved July 13, 2014, from http://www. merriam-webster.com/dictionary/game

game. 2014. In WordReference.com. Retrieved July 13, 2014, from http://www.wordreference.com/definition/game

Goggin, G. (2006). Cell phone culture: Mobile technology in everyday life. New York: Routledge.

Google. (2014). Word search. Retrieved from Aplicaciones: https://play.google.com/ store/apps/details?id=com.virtuesoft.wordsearch

Google. (2014). Category quiz. Retrieved from Aplicaciones: https://play.google. com/store/apps/details?id=hmas.category.quiz 
Google. (2014). Guess the emoji. Retrieved from Aplicaciones: https://play.google. com/store/apps/details?id=com.randomlogicgames.guesstheemoji

Google. (2014). Johnny grammar word challenge. Retrieved from Aplicaciones: https://play.google.com/store/apps/details?id=com.ubl.spellmaster\&\&referrer=utm_content\%3Dadbb660d-d034-46b9-8ac9-5b74be2d648c\%26utm_ medium\%3Dad-analytics\%26utm_source\%3Dflurry\%26utm_campaign\%3DLE\%252520Website

Google. (2014). English vocabulary test. Retrieved from Aplicaciones: https://play. google.com/store/apps/details?id=vocabulary.test

Google. (2014). Word shaker free. Retrieved from Aplicaciones: https://play.google. com/store/apps/details?id=com.afksoft.WordShakerAndroidFree

Google. (2014). Practice English grammar - Sam. Retrieved from Aplicaciones: https://play.google.com/store/apps/details?id=com.testsstore.app

Google. (2014). Hangman. Retrieved from Aplicaciones: https://play.google.com/ store/apps/details?id=com.ricardoalves.hangman.pt

Hockly, N. (2013, August 26). E-moderation station - Tools, tips, techniques, and tweets for online moderators. Retrieved from Mobile devices in EFL: What do students think?: http://www.emoderationskills.com/?p=1188

Korbey, H. (2014, June 9). Mind/Shift How we will learn. Retrieved from Surprising Insights: How Teachers Use Games in the Classroom: http://blogs.kqed.org/ mindshift/2014/06/surprising-insights-how-teachers-use-games-in-the-classroom/

Lee, K. J., \& Kim, J. E. (2013). A mobile-based learning tool to improve writing skills of EFL learners. Procedia-Social and Behavioral Sciences, 106, 112-119. Doi: https://doi.org/10.1016/j.sbspro.2013.12.014

Miangah, T. M., \& Nezarat, A. (2012). Mobile-assisted language learning. International Journal of Distributed and Parallel Systems, 3, 309-319. Retrieved from http://airccse.org/journal/ijdps/papers/0112ijdps26.pdf

Ministerio de Educacion (2012). The English language learning standards. Quito: MinEduc.Retrieved from http://educacion.gob.ec/wp-content/uploads/downloads/2012/09/estandares_2012_ingles_opt.pdf

Ministerio de Educacion (2014). Acuerdo ministerial 70-14: Regulaciones para el uso de teléfonos celulares en instituciones educativas. Quito: MinEduc. Retrieved from http://educacion.gob.ec/mineduc-expide-regulaciones-para-el-uso-de-telefonos-celulares-en-instituciones-educativas/ 
Ormiston, M. (2014, July 15). TeachHUB.com. Retrieved from How to Use Cell Phones as Learning Tools: http://www.teachhub.com/how-use-cell-phones-learning-tools

P’Rayan, A. (2011, June 8). Learning ESL/EFL using smartphones. Retrieved July 16, 2014, from British Council BBC: http://www.teachingenglish.org.uk/blogs/ admin/learning-esl-efl-using-smartphones

P'Ryan, A. (2012, March 6). British Council BBC. Retrieved July 16, 2014, from English learning apps for smart phones: http://www.teachingenglish.org.uk/ blogs/admin/english-learning-apps-smart-phones

Rodríguez-Arancón, P., Arus, J., \& Calle, C. (2013). The use of current mobile learning applications in EFL. Procedia - Social and Behavioral Sciences, 103, 1189-1196. DoiN https://doi.org/10.1016/j.sbspro.2013.10.446 00000aacb$35 \mathrm{f} \&$ acdnat $=1405565600 \_c 4 a 9692$ ebdde2c6d25a427b35d0a62 11

Shapiro, J. (2014, May 16). Mind/Shift How we will learn. Retrieved from Social And Emotional Benefits Of Video Games: Metacognition and Relationships: http://blogs.kqed.org/mindshift/2014/05/social-and-emotional-benefits-of-video-games-metacognition-and-relationships/

Todd, R. W., \& Tepsuriwong, S. (2008). Mobile mazes: Investigating a mobile phone game for language learning. CALL-EJ Online, 1. Retrieved from http://callej. org/journal/10-1/Watson-Todd.html

Upadhyay, S., \& Upadhyay, N. (2007). Mobile language class: Language learning through mobile gaming. International Journal of Instructional Technology and Distance Learning, 9, N/A. Retrieved from http://www.itdl.org/Journal/Sep_07/article03.htm

Verizon. (2014). Verizon Wireless. Retrieved from Apps. Bring Your World to Life.: http://www.verizonwireless.com/wcms/consumer/explore/apps-media.html 
Universidad Técnica de Machala

Ediciones UTMACH

Primera edición en inglés 2020

PDF interactivo 


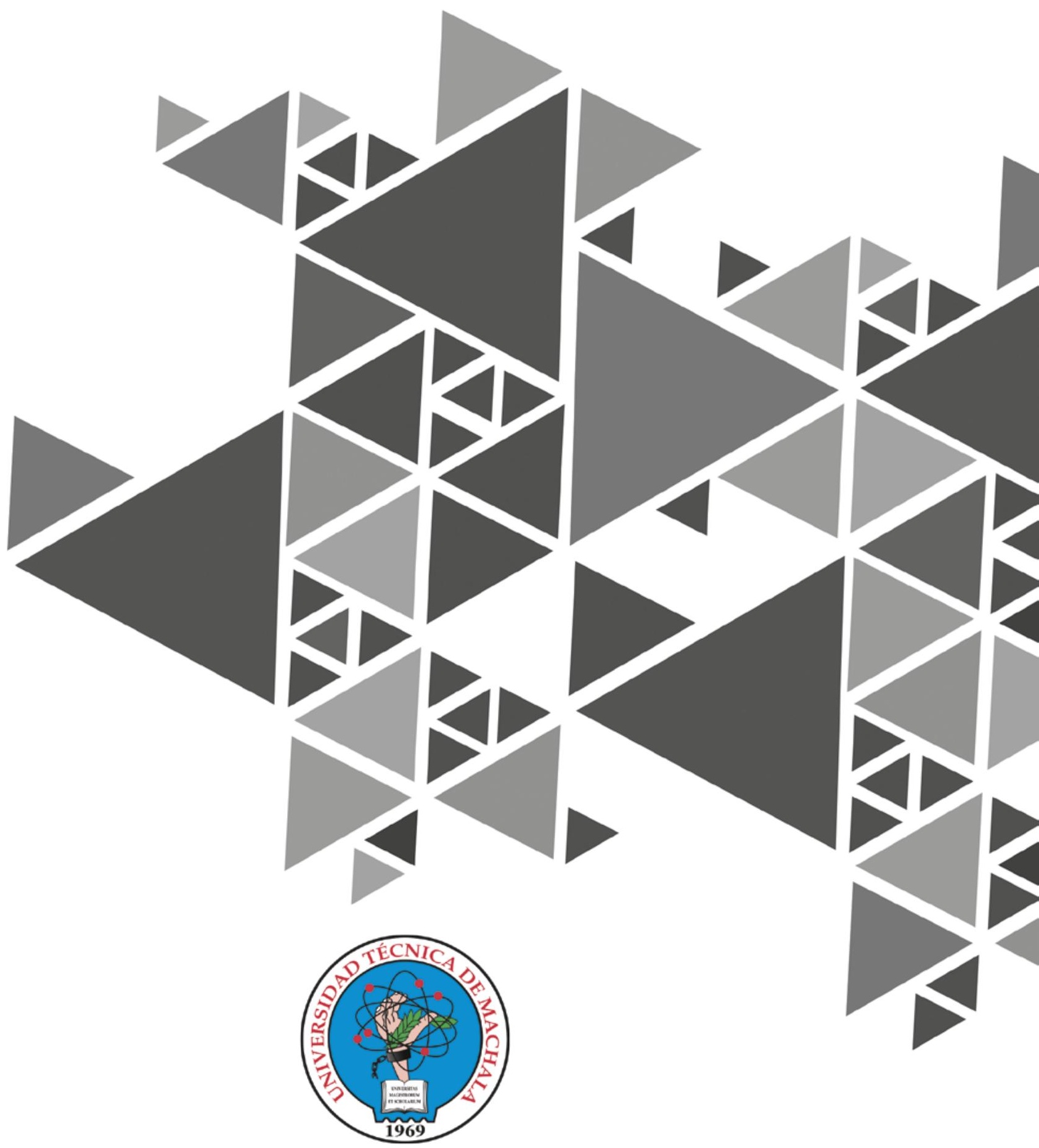

Universidad Técnica de Machala

Dirección de Investigación

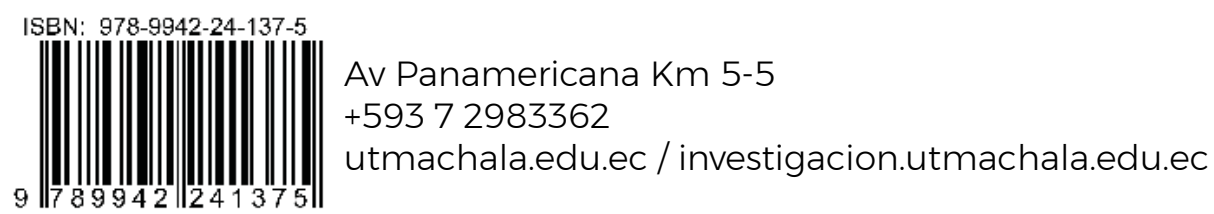

